\title{
The relationship between the cytokines and hs-CRP levels in children with autism and their comparison with healthy ones
}

\author{
Soleyman Ansari Kolachahi', Zahra Hoijati Zidashti ${ }^{2}$, Alireza Elmieh ${ }^{3}$, Elham Bidabadi', Jafar Filli $^{5}$ \\ ${ }^{1}$ PhD Student, Department of Physical Education, Rasht Branch, Islamic Azad University, Rasht, Iran \\ ${ }^{2}$ Associate Professor, Department of Physical Education, Rasht Branch, Islamic Azad University, Rasht, Iran \\ ${ }^{3}$ Assisstant Professor, Department of Physical Education, Rasht Branch, Islamic Azad University, Rasht Branch, Rasht, \\ Iran \\ ${ }^{4}$ Associate Professor, Department of child neurology, Guilan University of Medical Sciences, Rasht, Iran \\ ${ }^{5}$ Assisstant Professor, Department of Psychiatry, Guilan University of Medical Sciences, Rasht, Iran
}

\begin{abstract}
Background: Previous studies suggest that dysregulation of the immune system is involved in the pathophysiology of autism spectrum disorders (ASD). The aim of the present study was to investigate some pre-and anti-inflammatory cytokines in the serum of children with autism and healthy children and to determine the correlation between these cytokines and hs-CRP.

Materials and methods: Serum levels of IL-1 $\beta$, IL-1RA, IL-6, IL-10, TNF- $\alpha$ cytokines and hs-CRP were assessed in twenty boys with autism spectrum disorder, aged 6 to 14 years, and 20 healthy controls. To analyze the data, multivariate analysis of variance analysis was used to compare the variables in the two groups, and Pearson correlation coefficient was utilized to assess the relationship between the levels of the cytokines and hs-CRP at the level of 0,05. SPSS software version 21 was used.

Results: The results showed that the level of all cytokines as well as hs-CRP in the autistic group was significantly higher than normal children $(\mathrm{p}<0.001)$, but there was no statistically significant relationship between cytokines and hs-CRP levels in children with autism ( $p>0.05)$.

Conclusion: The results suggest that abnormal immune responses such as increased levels of cytokines can be served as one of the biological markers of ASD.

Keywords: Autism spectrum disorder, C-reactive protein, Inflammatory cytokines, Immune system.

Cited as: Ansari Kolachahi S, Hojjati Zidashti Z, Elmieh A, Bidabadi E, Filli J. The relationship between the cytokines and hs-CRP levels in children with autism and thier comparison with healthy ones. Medical Science Journal of Islamic Azad University, Tehran Medical Branch 2019; 29(3): 240-248.
\end{abstract}

Correspondence to: Zahra Hojjati Zidashti

Tel: +989111358572

E-mail: zahrahojjatizidashti@gmail.com

ORCID ID: 0000-0002-7058-1416

Received: 20 Nov 2018; Accepted: 31 Dec 2018 
مجله علوم يزشكى دانشگاه آزاد اسلامى

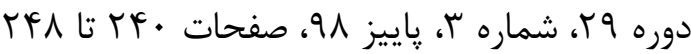

\section{ارتباط سطح سايتوكينها و hs-CRP در كودكان مبتلا به اوتيسم و مقايسه آنها باكودكان سالم}

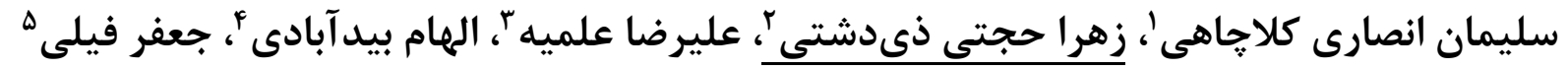

'دانشجوى دكترى فيزيولوزى ورزشى، گروه تربيتبدنى، واحد رشت، دانشگاه آزاد اسلامى، رشت، ايران

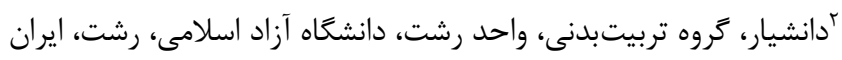

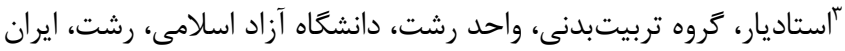

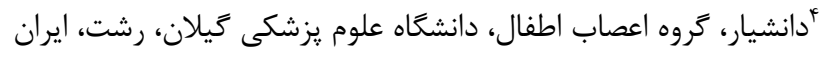

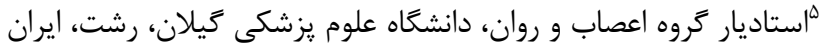

جكبده

سابقه و هدف: مطالعات بِيشين نشان مىدهند كه اختلال در سيسته /يمنى در بإتوفيزيولوزى اختلالات طيف /وتيسهم (ASD) دخالت

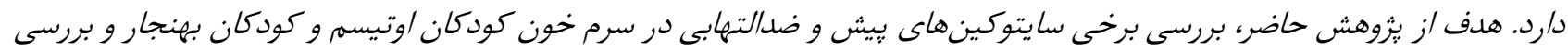

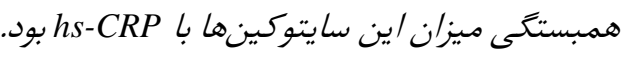
روش بررسى: سطح سرمى سايتوكينهاى IL-1B

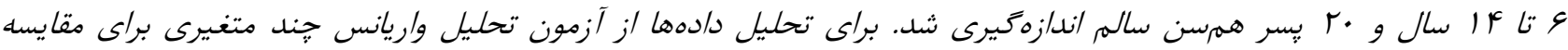

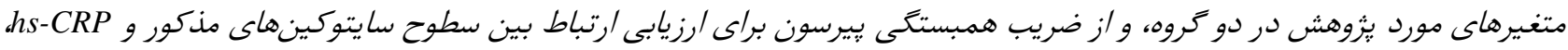
در سطح ه •/•> p ونرم/فزار SPSS نسخه الم /ستفاده شد.

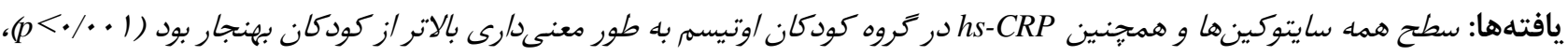

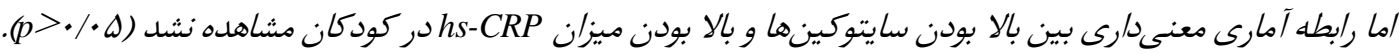

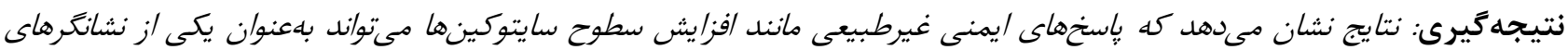
بيولوزيكى ASD/ستغاده شوند.

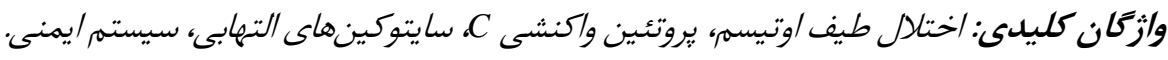

مىيابند (1). دو ويزگى اصلى ASD، نقص در تعامل و مقدمه

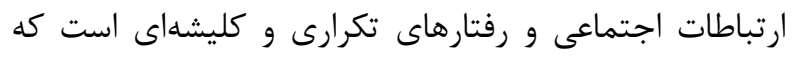

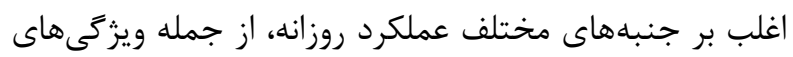
شناختى و حسى، كفتار و مهارتهاى بازى تاثير مى كذارند (1)

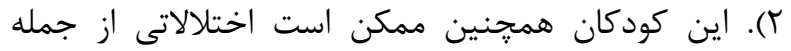

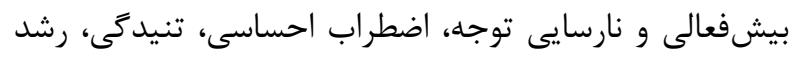

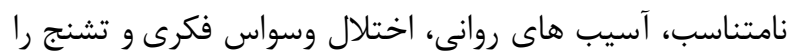

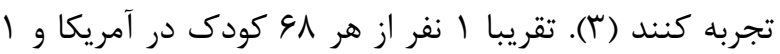
اختلالات طيف اوتيسم (ASDs) (Antism spectrum disorders) (ASDs)، اختلالات جديد نوروبيولوزيكى هستند كه در سه سال اول زندگى ظاهر مىشوند و تا اواخر دوران زندكى ادامه 
به عنوان تنظيمكننده بازخورد منفى در پاسخ به افزايش سطح

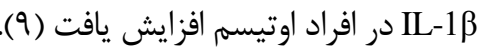
برخى ديخر از سايتوكينهاى بيشالتهابى مانند 6 در ياسخ ايمنى سلول دخالت دارند و توسط مغز به عنوان سيخنال هاى مولكولى بيمارى شناخته مي شوند (1 (1). TNF-

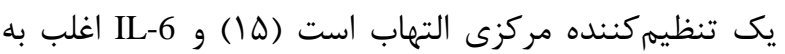
عنوان نشانكر براى فعالسازى سيستميك سايتوكينهاى ״يش التهابى استفاده مىشود. مانند برخى سايتو كين هاى ديخر، داراى خواص ييش و ضد التهابى است و مانع توليد IL-6 و TNF- $\alpha$ و و همكارانش در نمونههاى يس از مرگ نشان داده است كه سطح يروتئين TNF- و IL-6 در مغز افراد مبتلا به اوتيسم

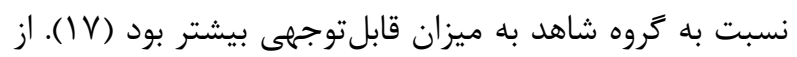
سوى ديخر، در يك مطالعه نشان داده شد كه اختلاف سطوح يلاسمايى TNF- بين كودكان مبتلا به اوتيسم و عادى به

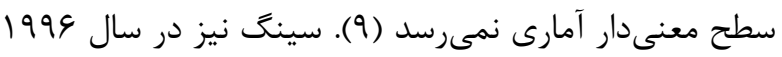
نشان داد كه تفاوت معنى دارى ندارد (11). مهرمترين سايتوكين ضدالتهابى كه در ياسخ ايمنى بدن انسان يافت مىشود، IL-10 است. اين سايتوكاين به شدت مانع توليد IL-6 TNF- $\alpha$ IL-1 ديگر مىشود. اثرات مهارى آن بر توليد IL-1 و TNF فعاليتهاى ضدالتهابى آن بسيار مهرم است، زيرا اين سايتوكينها اغلب فعاليتهاى همافزايى بر مسيرها و فرآيندهاى التهابى دارند (9 (). افزايش سطح IL-10 همراه با TGFموجب كاهش التهاب شود (1). (1). يك مطالعه در مورد كودكان اوتيسم در سن IL-1f سال نشان داد كه توليد IL-10 توسط سلولهاى تكهستهاى خون محيطى ( peripheral blood ) تحريك شده با اينترلوكين-1 (PBMC) (mononuclear cells در افراد مبتلا به اوتيسم پايينتر از افراد عادى بود؛ همجنين شوارتز و همكاران، تغيير سطوح اينترلوكين-• إن را در مردان

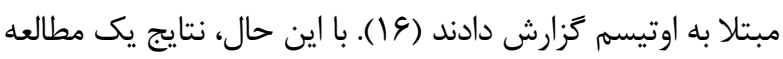

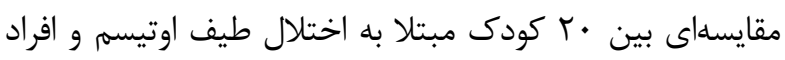
سالم نشان داد كه هيج افزايش جبرانى در سايتوكين تنظيمى دئى IL-10 نشانگر مفيد ديخر براى ارزيابى نتايج درمان در بيماران مبتلا

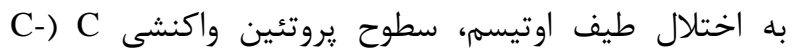
(CRP) (reactive protein خانواده ينتراكسين، يك يروتئين مهم فاز حاد و يك نشانگر

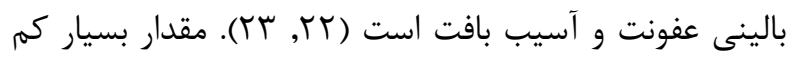

نفر از هر •ها كودك در ايران مبتلا به اختلال اوتيسم تشخيص داده مىشوند ( ا, أ) و يسران أ تا • ا برابر بيشتر از

دختران مبتلا مى شوند (ه). علاوه بر علايم اصلى، مشكلات فراوانى شامل اختلال خواب، صرع، عدم تحمل غذا، اختلال در دستخاه گَوارش، اختلال خلقى و رفتارهاى يرخاشگرانه و خودآسيبزا (ع) و و اختلالات سيستميك مانند اختلالات حركتى، مشكل در نيمرخ ساختارى و قامتى، راه رفتن، تعادل و تحرك مفصل (V) با ASD همراه هستند. اگرجه علت ASD هنوز مشخص نيست، احتمالا شامل رهل تعاملات ييجيده بين عوامل زنتيكى، إِيىزنيكى و محيطى مىشود (^). تحقيقات اخير نشان مىدهند كه اختلال در سيستم ايمنى در ياتوزنز طيف اوتيسم دخالت دارد. در افراد

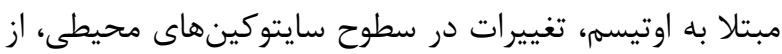

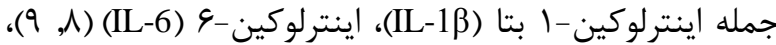

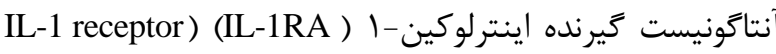
(9) (antagonist اينترلوكين-• (IL-10) (·) (1) مشاهده شده است. بنابراين تعجب آور نيست كه اين سايتوكينها به عنوان نشانكر پاسخ غيرطبيعى در افراد مبتلا به اوتيسم به كار روند. از سوى ديخر،

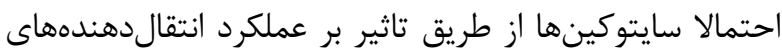
عصبى، فعاليت عصب-غدد درونريز، نوروزنز و تغييرات در مغز بر رفتار موثر باشند (1)-1 (1). به عنوان مثال، افزايش سطح و IL-6 مىتواند بر شدت رفتارهاى كليشهاى تأثير بحذارد (N). علاوه بر اين، هرگونه اختلال در تنظيم IL-13 در اختلالات حافظه و يادگيرى دخالت دارد (r (). سايتوكينها يروتئينهايى هستند كه شدت، مدت و ويزگى ياسخ

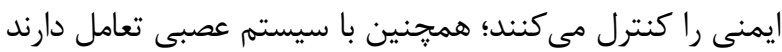
و در رشد و حفظ عصبى نقش دارند (I IL). IL-1 ييشالتهابى است كه از منابع مختلفى از جمله مونوسيتها،

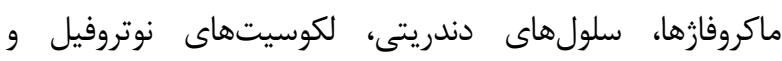
سلولهاى اندوتليال ايجاد مىشود (9)، به وسيله مغز در ياسخ به محركهاى التهابى محيطى توليد مىشود و به آرامى به سمت مغزى سد خونى - مغزى با انتقال حجم منتشر مىشود (1/). در

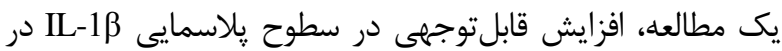

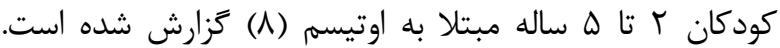
همجنين نتايج يزوهش ديگرى نشان داد كه غلظتهاى

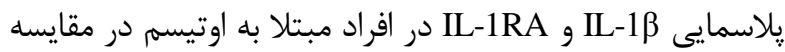
با مقادير مربوط به همتايان سالم به طور قابلتوجهى بيشتر است (9). علاوهبراين، افزايش سطح پيلاسمايى IL-1RA در كودكان

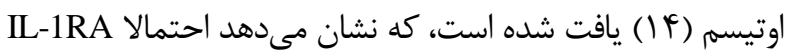


كودكان حاضـر در مطالعـهـ بــا والـدين خـود زنـدكى مسى كردنـد. يرسشنامهها براى جمعآورى اطلاعات مربوط به جمعيتشناسىى، دورئ

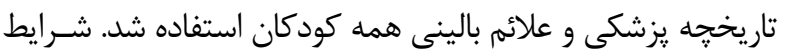

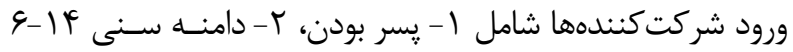

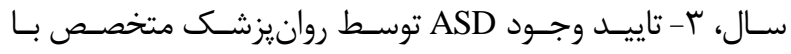
استفاده از يرسشنامه DSM-5 و \& أ) نداشتن ناتوانى همراه بود.

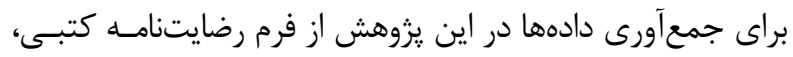

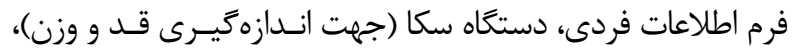

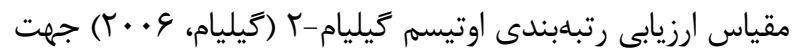

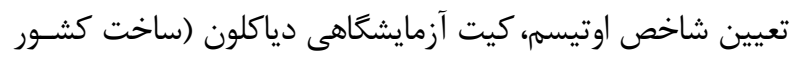

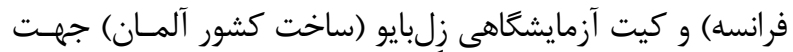

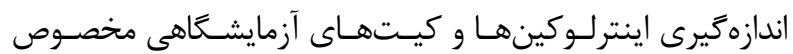
اندازهيرى ويتامين D و hs-CRP استفاده شد.

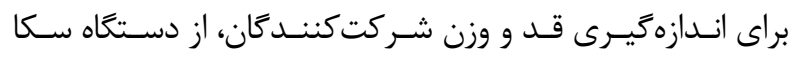
ساخت كشور آلمان استفاده شد. (SECA)

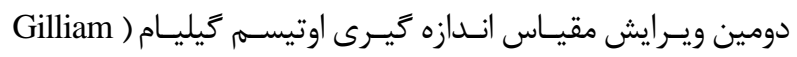
(Autism Rating Scale-2 (Gars-2) كه براى ارزيابى اشخاص اوتيسم و ديخر اختلالات رفتـارى شـديد

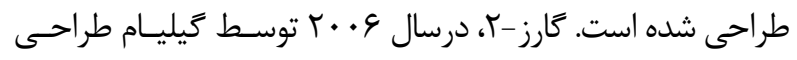

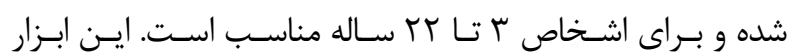

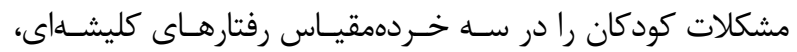

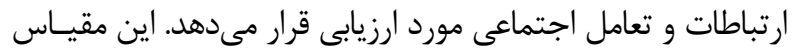

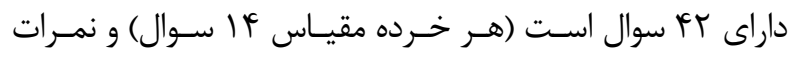

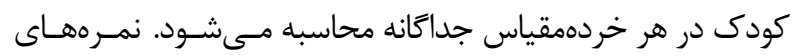
تركيبى در اين خردهمقياسها، يك امتياز نسبت به اوتيسـم را بــهـ

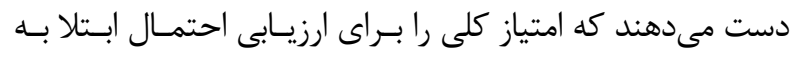

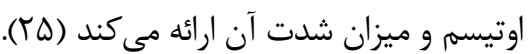

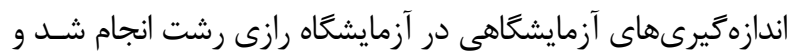

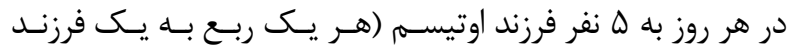

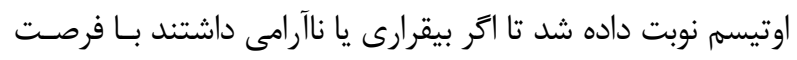
بتوان آنهـا را آرام كـرد و كـودك ديخـر اوتيسـم در معـرض ايـن نآرامىها قرار نخيرد) و ه نفر كودك عادى نوبـت داده شـد. تمـام

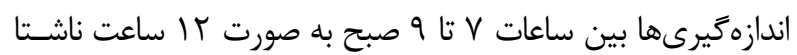

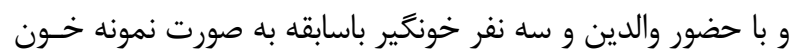

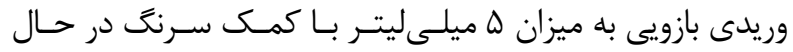

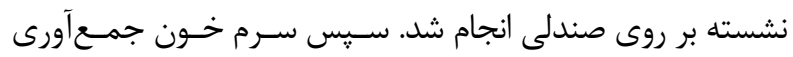

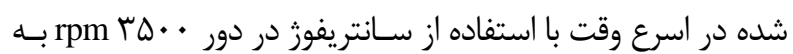
مدت • ا دقيقه در دماى F درجه سـانتى ₹ـراد جداسـازى شـد و تمام سرمها به منظور به حــاقل رسـاندن ضـريب تغييـرات بـين
( high sensitivity) hs-CRP توسط استفاده از CRP

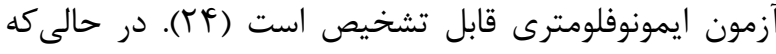

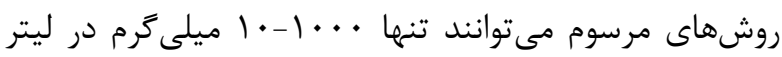
را تشخيص دهند، آزمايش حساسيت بالا مىتواند ه| • CRP • ا ميلى زرم در ليتر اين يروتئين را تشخيص دهد. خاكزاد و

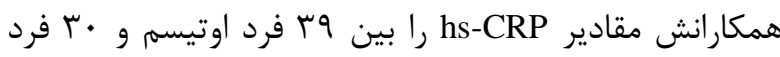
سالم مقايسه كردند. نتايج نشان داد كه ميانگين غلظت در كود كان مبتلا به اوتيسم به طور معنى دارى بيشتر از گروه شاهد بود و همبستخى مثبت بين غلظت hs-CRP و hs- شدت اوتيسم وجود داشت. بنابراين، برخى ممكن است مدوه

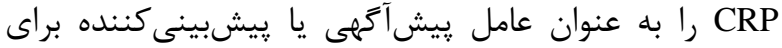
اوتيسم در نظر بخيرند، اما هنوز نقش اين يروتئين در كودكان

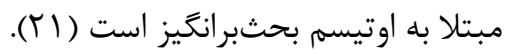
بررسى مطالعات ييشين حاكى از آن است كه در ايران، هيج مطالعهاى تاكنون به بررسى سطوح سايتوكينهاى التهابى در

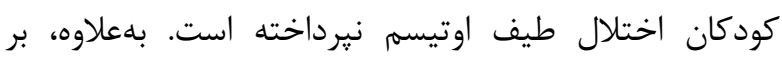
اساس آخرين گزارشها، هنوز تحقيقى در زمينه بررسى ارتباط سطوح سايتوكينها و hs-CRP در كودكان مبتلا به اختلال طيف اوتيسم اجرا نشده است. از اين رو مطالعه حاضر با اهداف زير اجرا شد: الف) ارزيابى سطوح سرمى جند سايتوكين ييش و ضد التهابى (IL-1 يسران \& تا \& أ ساله مبتلا به اختلال طيف اوتيسم و مقايسه ميزان سطوح سرمى اين سايتوكينها در كودكان مبتلا به به بهان

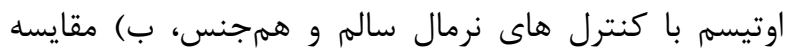
سطح سرمى hs-CRP بين كودكان ASD و كودكان عادى، و در نهايت ج) هدف فرعى اين مطالعه، بررسى اين است كه آيا ارتباطى بين سطوح hs-CRP و سايتوكينهاى مذكور در هرو كود كان مبتلا به اوتيسم وجود دارد.

\section{مواد و روشهيا}

مطالعه حاضر از نوع تحقيق مقطعى با هـدف توصـيف، مقايسـهـ و

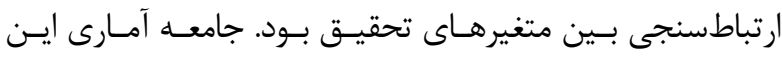
يزوهش، شامل و9 دختر و يسـر مبـتلا بــ ASD عضـو موسسـهـ خيريه انجمن اوتيسم گيلان و دانش آموزان همتــاى سـالم سـاكن

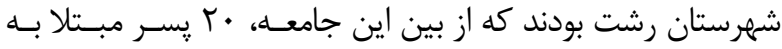

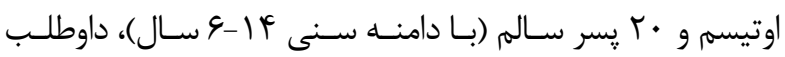

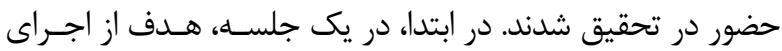
اين مطالعه براى والدين همه كودكان تشريح شد. ســــ، قبـل از

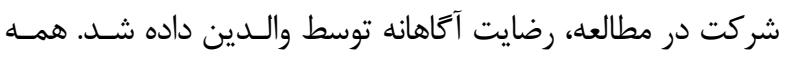


اسميرنف (K-S Z) براى بررسى نرمال بودن توزيع متغيرها Fزارش شدهاند. نتايج جدول r نشان مىدهد كه آماره

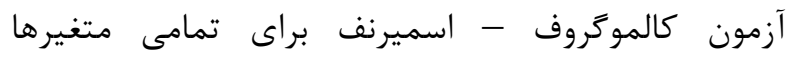
معنى دار نيست؛ بنابراين توزيع متغيرها نرمال است.

جدول r. شاخص هاى توصيفى متغيرهاى يزوهش و نتايج بررسى نرمال بودن توزيع متغيرها (تعداد در هر كروه= • (Y)

\begin{tabular}{|c|c|c|c|c|c|}
\hline$p$ & $K-S Z$ & انحراف استاندارد & ميانگين & كروه & متغير \\
\hline $.19 V$ & $\cdot / 4 \wedge$ & $1 / 9$ & $V / \mathbb{A}$ & اوتيسم & IL-1 $\beta$ \\
\hline$\cdot / V F$ & $\cdot 191$ & $\cdot / \Delta r$ & $r / 9 V$ & عادى & \\
\hline .119 & $1 / \cdot V$ & $r / V \Delta$ & $\Delta / 9 \Lambda$ & اوتيسم & IL-6 \\
\hline$\cdot 1 \cdot V$ & $1 / 79$ & $\cdot / 4 \Delta$ & $1 / 1 F$ & عادى & \\
\hline.$/ 14$ & $1 / 10$ & FV/TK & QV/VD & اوتيسم & IL-1RA \\
\hline$\cdot 10 \cdot$ & - IAT & سז/rו & $\mid \mathrm{V} / \cdot \mathrm{G}$ & عادى & \\
\hline$\cdot 1 \cdot V$ & $1 / \Gamma \Lambda$ & r/A & $11 / .9$ & اوتيسم & TNF- $\alpha$ \\
\hline .191 & $\cdot \mid \Delta \Delta$ & $\cdot|\Lambda|^{2}$ & $T / T V$ & عادى & \\
\hline . 194 & • & l/Ar & $V / r I$ & اوتيسم & IL-10 \\
\hline$\cdot / r \Lambda$ & $\cdot / 91$ & ./VG & T/RG & عادى & \\
\hline .199 & $\cdot|V|$ & $1 / V V$ & r/VA & اوتيسم & hs-CRP \\
\hline$\cdot / V F$ & $\cdot 181$ & $\cdot \mid \Delta F$ & $\cdot / A V$ & عادى & \\
\hline
\end{tabular}

براى بررسى تفاوت كودكان مبتلا به اوتيسم و كودكان

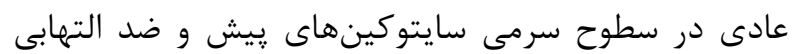
و و همجنين-IL-10 TNF- $\alpha$ ،IL-1RA ،IL-6 ،IL-1 از تحليل واريانس جندمتغيرى يك راهـ استفاده شد. در جدول س، نتايج آزمون تحليل واريانس جند متنغيرى كزارش شده است. با توجه به جدول گr آماره F تحليل

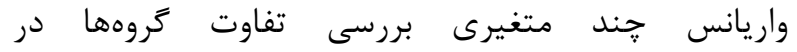

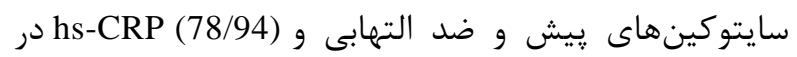
سطح I • • • معنى دار است. بنابراين مىتوان كفت كه بين اين دو گروه در سايتوكينهاى پيش و ضدالتهابى و و تفاوت معنى دارى وجود دارد. hs-CRP

جدول س. نتايج آزمون تحليلواريانس جندمتغيرى مربوط به

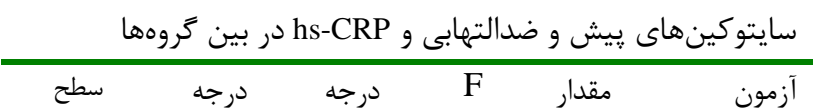

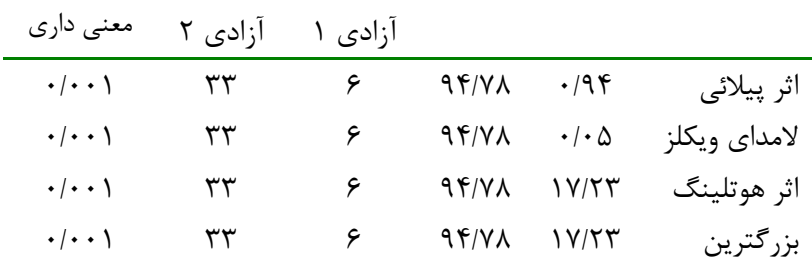
ريشه روى نوري
آزمايش تا روز انجام يك آزمايش واحد بر روى تمـام نمونسههـا، در فريزر در دماى • ·- درجه سانتى

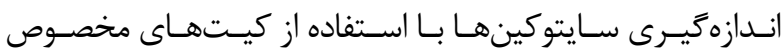

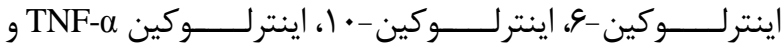
اينترلوكين ا -ر دياكلون (Diaclone) ساخت كشور فرانسه و بـراى

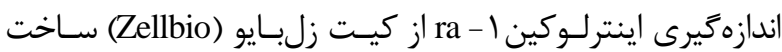
كشور آلمان بر اساس دستورات شركت توليدكنـــده و روش الايـزا استفاده شد. حساسيت حداقل محدوده كثـف بـراى سـايتوكين-

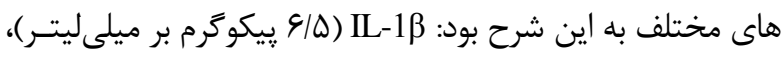
- (ه نانوگرم بر ميلىليتـر)، IL-1RA

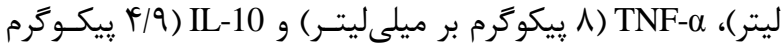

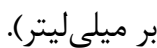

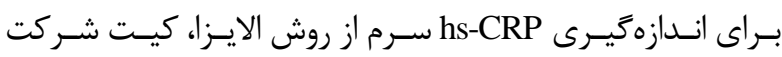
يارسآزمون ساخت كشور ايران استفاده شد.

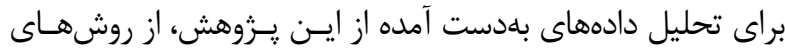

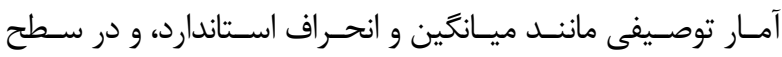

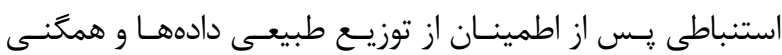

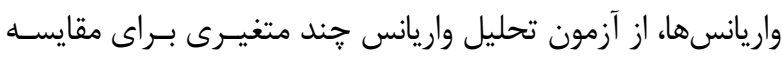

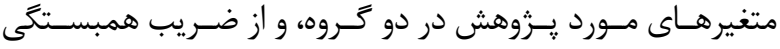
ييرسون براى ارزيابى ارتباط بين سطوح سايتوكينهـاى مـذكور و

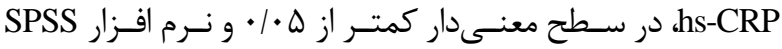
نسخه آ استفاده شد.

\section{كافتهها}

در جدول ا، شاخصهاى توصيفى سن، قد، وزن و BMI در گروه كودكان داراى ASD وكود كان سالم ززارش شده است.

جدول ا. مشخصات فردى كودكان اوتيسم و كودكان سالم (تعداد

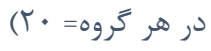

\begin{tabular}{|c|c|c|c|c|}
\hline ميانخين & بيشينه & كمينه & 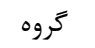 & متغير \\
\hline $1 \cdot / r \cdot$ & If & \& & اوتيسم & سن \\
\hline $1 \cdot / \pi \cdot$ & If & 4 & 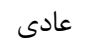 & \\
\hline $1 / 49$ & $1 / 8 \wedge$ & $1 / T \wedge$ & اوتيسم & قد ق \\
\hline $1 / 4 V$ & $1 / 99$ & $1 / \pi \Delta$ & عادى & \\
\hline$\Delta \Lambda / T \cdot$ & Ar & r. & اوتيسم & وزن \\
\hline$\uparrow q / F \Delta$ & 99 & ५q & عادى & \\
\hline$r \varepsilon / \cdot \Delta$ & $r \cdot \mid q r$ & $r \cdot / \Delta \Delta$ & اوتيسم & نمايه توده بدن (BMI) \\
\hline Tr/VY & $r v / r q$ & $19 / \wedge \Delta$ & عادى & \\
\hline
\end{tabular}

در جدول r، شاخصهاى توصيفى متغيرهاى يزوهش به

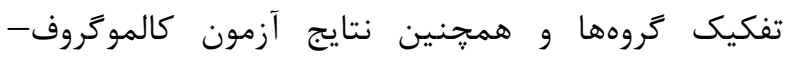


جدول ه، ميانگين كودكان مبتلا به اوتيسم در سايتوكينهاى بيش و ضدالتهابى (IL-13، (TL-10 TNF- $\alpha$

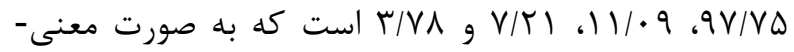
دارى بيشتر از ميانكَين كودكان سالم است. ميانكَين

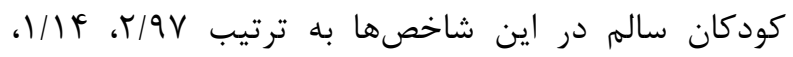
( براى بررسى رابطه سايتوكينها و سطح سرمى hs-CRP در

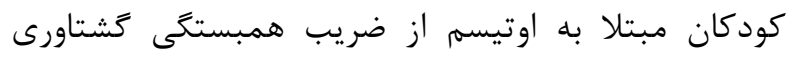
ييرسون استفاده شد. در جدول 9 ماتريس همبستكى رابطه
براى بررسى تفاوت گروهها در سايتوكينهاى ييش و

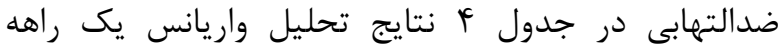

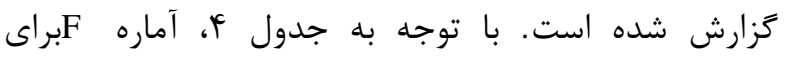

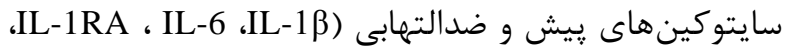

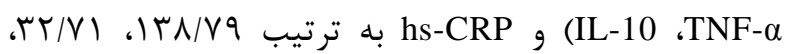

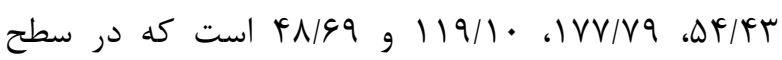

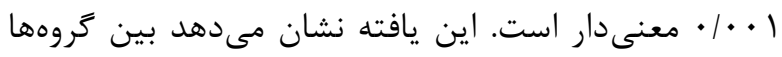
در اين متغيرها تفاوت معنى دارى وجود دارد.

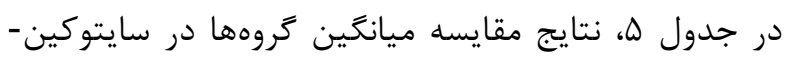

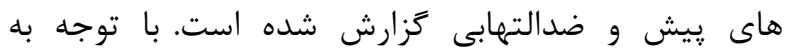

جدول F. نتايج تحليل واريانس يكراهه تفاوت تروه ها در سايتوكينهاى بيش و ضد التهابى

\begin{tabular}{|c|c|c|c|c|c|c|}
\hline $\mathrm{p}$ & $\mathrm{F}$ & خطا MS & كروه & خطا & كروه SS & مولفه \\
\hline.$/ .1$ & 1 Ir/Vq & $1 / 4 \pi$ & $199 / \Gamma 1$ & $\Delta F / \Delta V$ & $199 / \% 1$ & IL-1 $1 \beta$ \\
\hline $.1 . .1$ & rT/VI & $V / 1 Q$ & $r m F / l$ & $r V I / 9 \Delta$ & $r M F / 1$ & IL-6 \\
\hline $.1 . .1$ & $\Delta F / F T$ & 1199119 & $901 \cdot 1 / V G$ & $F \Delta F \Delta F / T q$ & $Q \Delta 1 \cdot \wedge / V G$ & IL-1RA \\
\hline $.1 . .1$ & IVV/Vq & $r / T V$ & VVV/9D & $199 / \%$. & $V V V / 9 D$ & TNF- $\alpha$ \\
\hline$\cdot / . .1$ & $119 / 1$. & $1 / 9 \mathrm{~V}$ & TrF/VA & $V * / 91$ & THY/VA & IL-10 \\
\hline.$/ . .1$ & $\forall N / 99$ & $1 / N r$ & $\lambda F / \Psi q$ & QD/AT & $\lambda F / \widetilde{G}$ & hs-CRP \\
\hline
\end{tabular}

جدول ه. نتايج مقايسه ميانگين گروهها در سايتوكينهاى يُيش و ضدالتهابى

\begin{tabular}{|c|c|c|c|c|c|}
\hline سطح معنى دارى & خطاى استاندارد & تفاوت ميانكَين & ميانكين & كروه & متغير \\
\hline \multirow[t]{2}{*}{$\cdot / .1$} & $\cdot / \mu V$ & $F / 4 \varepsilon$ & $V / F r$ & اوتيسم & IL-1 $\beta$ \\
\hline & & & $r / 9 V$ & عادى & \\
\hline \multirow[t]{2}{*}{$.1 . .1$} & $\cdot / A F$ & F/AT & $\Delta / 9 \Lambda$ & اوتيسم & IL-6 \\
\hline & & & $1 / 14$ & عادى & \\
\hline \multirow[t]{2}{*}{$.1 . .1$} & $1 . / 94$ & $1 \cdot 199$ & qV/VD & اوتيسم & IL-1RA \\
\hline & & & $|V| \cdot 4$ & عادى & \\
\hline \multirow[t]{2}{*}{$.1 . .1$} & .199 & $N / N)$ & $11 / \cdot 9$ & اوتيسم & TNF- $\alpha$ \\
\hline & & & $r / r V$ & عادى & \\
\hline \multirow[t]{2}{*}{$.1 . .1$} & $\cdot / 4 F$ & $F / A F$ & $V / T I$ & اوتيسم & IL-10 \\
\hline & & & T/RG & عادى & \\
\hline \multirow[t]{2}{*}{$.1 . .1$} & $\cdot|4|$ & $r / 9$. & r/vi & اوتيسم & hs-CRP \\
\hline & & & $\cdot / \mathrm{AV}$ & عادى & \\
\hline
\end{tabular}

جدول 9. ماتريس همبستخى R بين سايتو كينهاى پيش و ضدالتهابى و سطح سرمى hs-CRP در كودكان مبتلا به اوتيسم

\begin{tabular}{|c|c|c|c|c|c|c|c|}
\hline 9 & $\Delta$ & i & r & r & 1 & متغير & شماره \\
\hline & & & & & 1 & IL-1 $\beta$ & 1 \\
\hline & & & & 1 & $\cdot / F^{\prime}$ & IL-6 & $r$ \\
\hline & & & 1 &.$- / 1 r$ & rאו. & IL-1RA & $r$ \\
\hline & & 1 & .1 .1 & .1 .9 & -.1 .1 & TNF- $\alpha$ & f \\
\hline & 1 & $-\cdot 11$ & $\cdot 111$ & $\cdot / \cdot r$ &.$- / . r$ & IL-10 & $\Delta$ \\
\hline 1 &.$/ K \varepsilon$ &.$- \cdot 1 \cdot V$ &.$- / K T$ & .119 &.$- / \cdot 1$ & hs-CRP & 9 \\
\hline
\end{tabular}


و IL-6 را به عنوان نشانهای مولكولى بيمارى شناسايى مىكند.

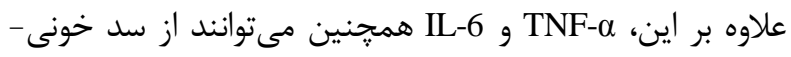

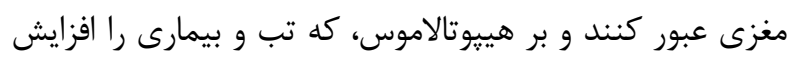

مى مهد، عمل نمايد (b) (1).

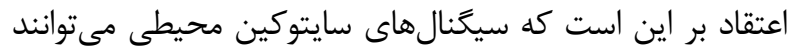

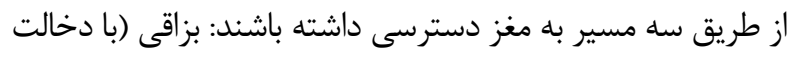

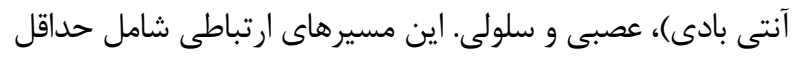

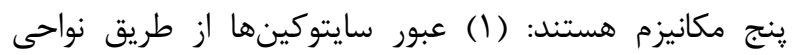

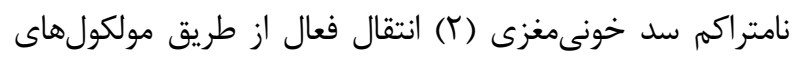

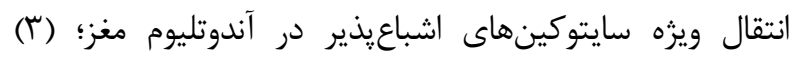

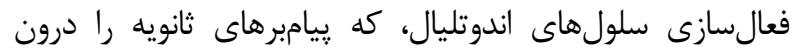

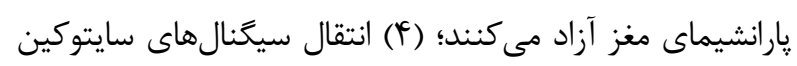

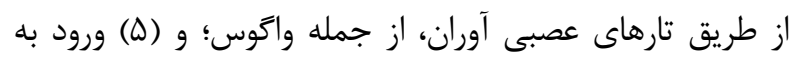
يارانشيماى مونوسيتهاى فعالشده محيطى مغز كه سايتوكينها

$$
\text { را آزاد مى كنند (T) (T). }
$$

سايتوكينها مىتوانند از طريق اثر بر عملكرد انتقال دهنده عصبى،

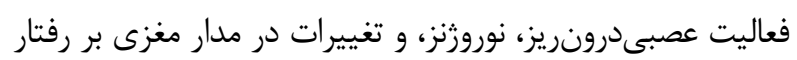

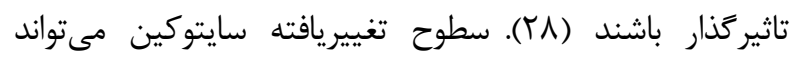

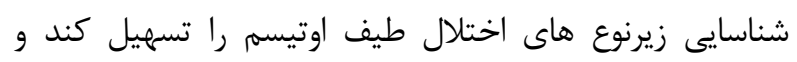

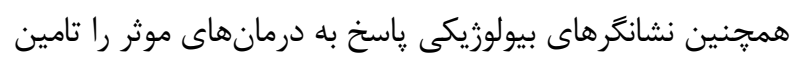

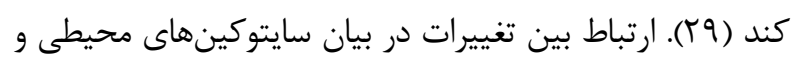

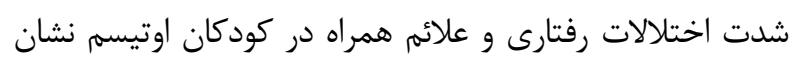

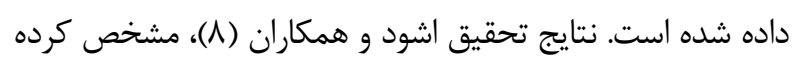

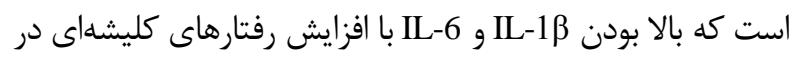

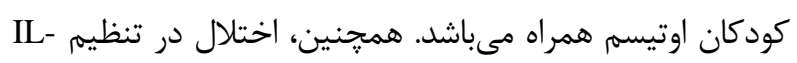

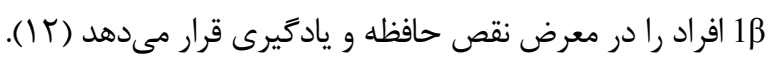

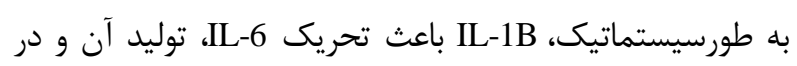

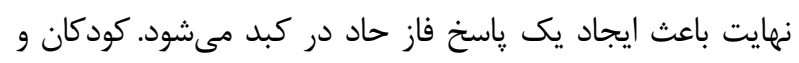

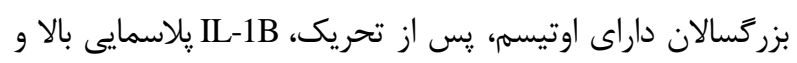

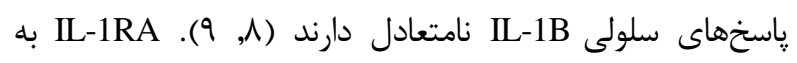

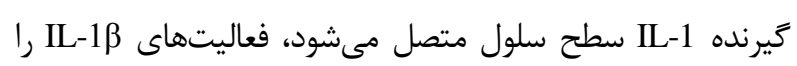

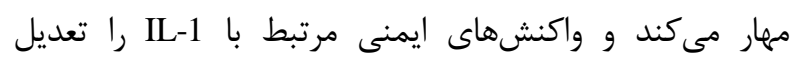
مى كند. افزايش IL-1ra در اوتيسم در تلاش براى موائ موازنه كردن

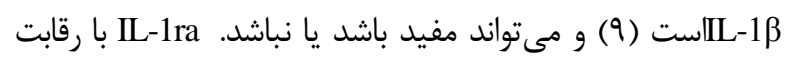

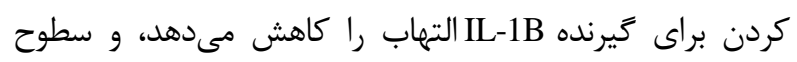

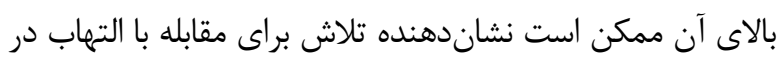

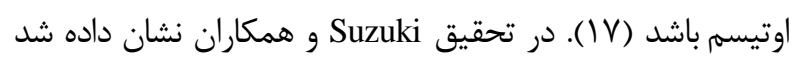

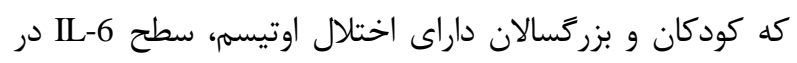
كردش بالاترى را در مقايسه با افراد داراى رشد معمولى دانى داشتند
بين اين متغيرها گزارش شدهاند. با توجه به جدول 9، رابطه معنى دارى بين سايتوكينهاى IL-1B TNF- $\alpha$

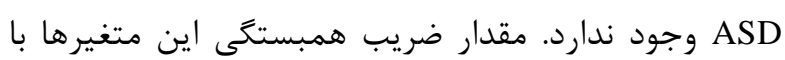

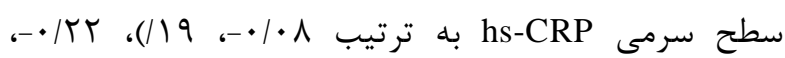

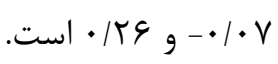

بحث

IL- هدف يزوهش حاضر، مقايسه سطوح سرمى سايتوكينهاى

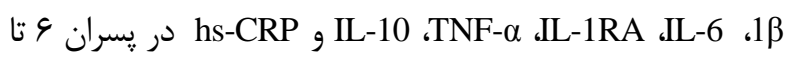

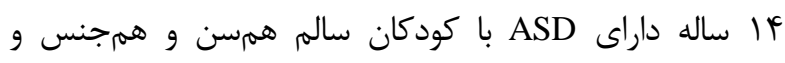

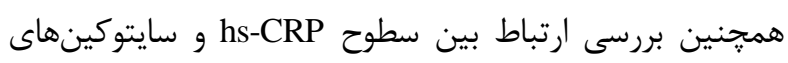

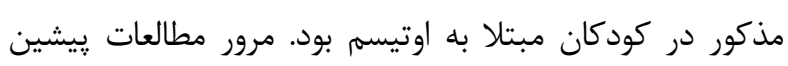

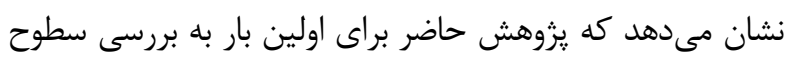

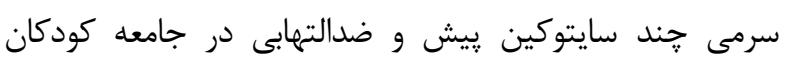

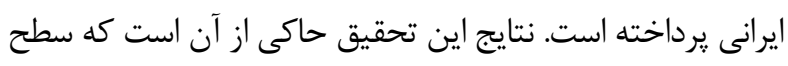

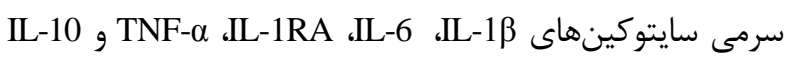

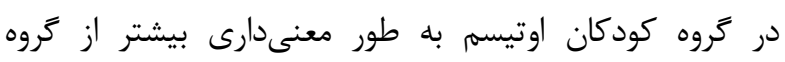

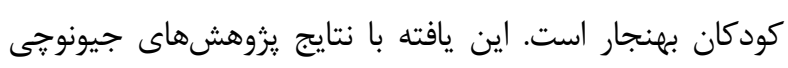

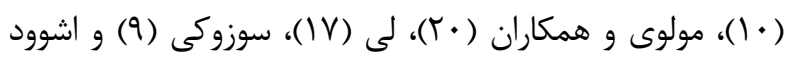

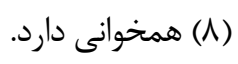

اكر جه علت ASD به طور واضح مشخص نيست، مطالعات اخير

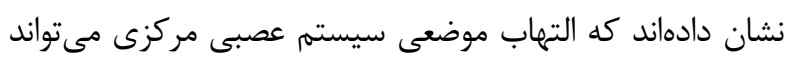

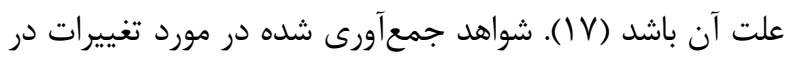

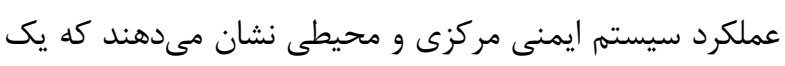

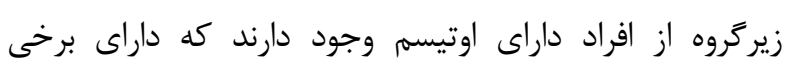

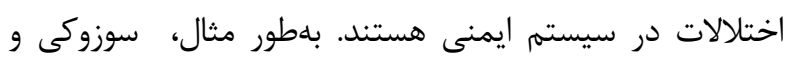

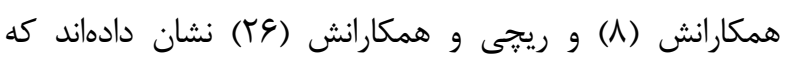

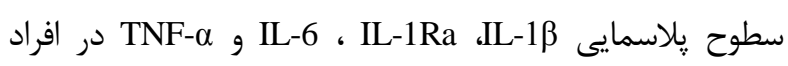
داراى اختلال طيف اوتيسم بالاتر از افراد سالم است.

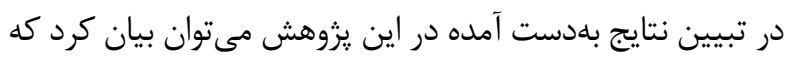
سيستم ايمنى بدن و سيستم عصبى به شدت با با هم تعامل دارند.

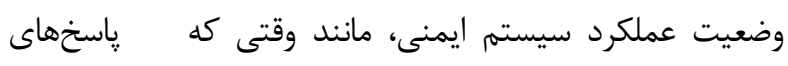

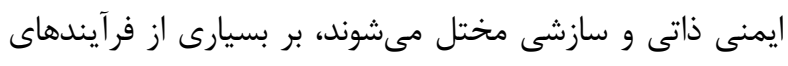

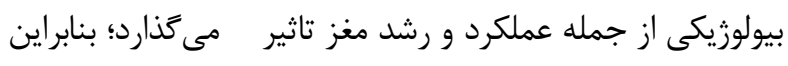

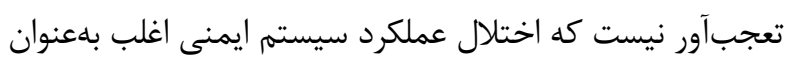

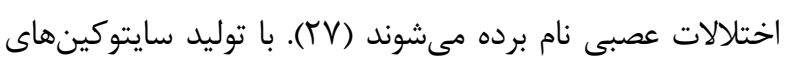

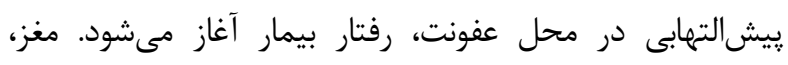

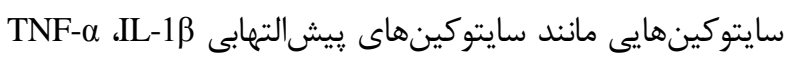


ايمنى ذاتى ثانويه در دستَاه عصبى مركزى (CNS) يا نشانگر يك رويدادى مثل عفونت در CNS است. اما، وجود ارتباط به

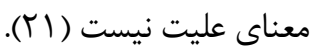
در مجموع، يافتههاى يزوهش حاضر نشان داد سطح سرمى مإى سايتوكينهاى IL-1 همجنين hs-CRP در رِيران مبتلا به اختلالات طيف اوتيسم به طور قابلملاحظهاى بالاتر از يسران سالم همسن آنان است، اما

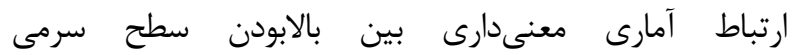
سايتوكينهاى موردنظر با سطح سرمى hs-CRP مشاهده نشد.

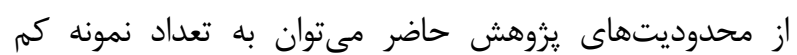
تحقيق اشاره كرد. ييشنهاد مىشود محققان در يزوهشهاى آينده به بررسى عوامل اثرگذار در افزايش عوامل التهابى در كودكان اوتيسم بيردازند.

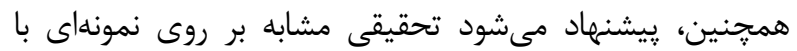
تعداد بيشتر، ردههاى سنى متفاوتتر از جمله اطفال و گِ يس از

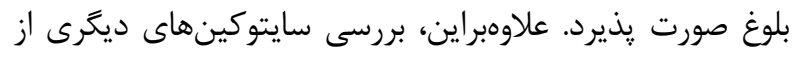

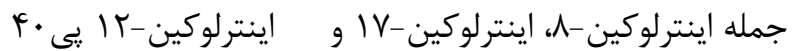
در زروه كودكان اوتيسم توصيه مىشود.

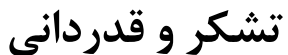

مطالعه حاضر، حاصل از رساله دكترى رشته فيزيولـوزى ورزشىى،

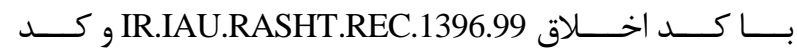

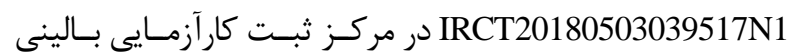
است. بدينوسيله از تمام يرسنل موسسه خيريسه اوتيسـم گَيلان،

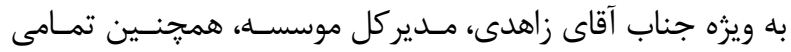

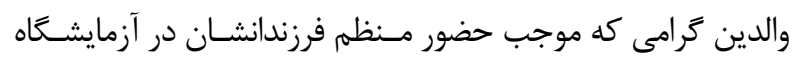

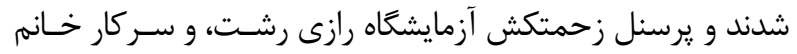

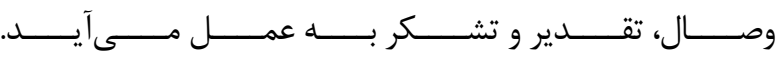

جيونوجى و همكاران VI كودك مبتلا به اوتيسم را با خواهران و برادران سالم و ساير كنترلها مقايسه كردند ( • (). يافتههاى آنها نشان داد كه سطح TNF- $\alpha$ TL-1 و و IL-6 در بيشتر كودكان اوتيسم ( / / د درصد) نسبت به گروه شاهد بالاتر بود. محققان نتيجه كرفتند كه اكثر كودكان اوتيسم در گروه، به ويزه افرادى كه داراى TNF-

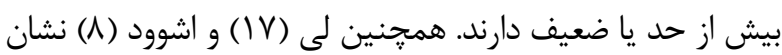

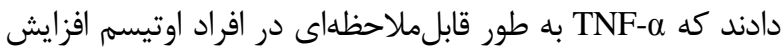
داشته است. IL-10 نيز، كه كاهشدهنده شدت ياسخ التهاب با يايين آوردن توليد سايتوكين قيش التهابى در بافت آسيب ديده

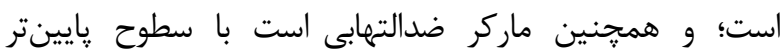

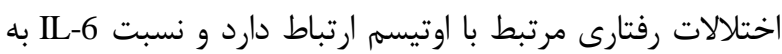
IL-10 با نقص رفتار اجتماعى مرتبط است (•r). در يزوهش حاضر، همجنين سطح سرمى hs-CRP در گروه كودكان مبتلا به اوتيسم بهطور قابلملاحظهاى بالاتر از گروه

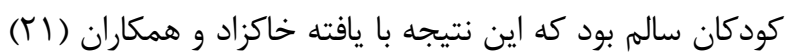

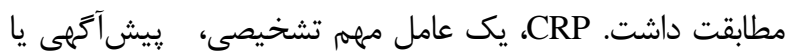
ييشبينى كننده براى اوتيسم است. البته وجود ساير نشانكرهاى التهابى در اوتيسم بايد مورد بررسى قرار گيرد تا تأييد شود كه آيا لئ فرايند التهاب در بروز اوتيسم نقش مهمى دارد. در ادامه نتايج تحقيق حاضر، با بررسى همبستخى بين سايتوكينهاى مذكور و

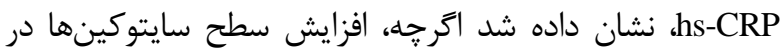

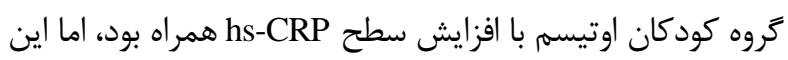
افزايش از لحاظ آمارى، داراى ارتباط معنى دارى نبود. مى بوتوان

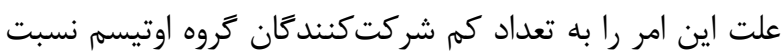
داد. hs-CRP، در كبد توسط عوامل بيش رالتهابى IL-6 و به ميزان كمترى توسط IL-13 و TNFدر فاز حاد بيمار سنتز مىشود، به سرعت در طى 4 تا 1 ساعت

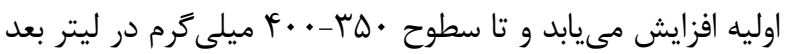

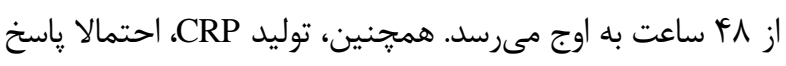

\section{REFERENCES}

1. American Psychiatric Association. Diagnostic and Statistical Manual of Mental Disorders, 5th ed. Arlington, VA: American Psychiatric Publishing; 2013.

2. Developmental Disabilities Monitoring Network Surveillance Year 2010 Principal Investigators; Centers for Disease Control and Prevention (CDC). Prevalence of autism spectrum disorder among children aged 8 years - autism and developmental disabilities monitoring network, 11 sites, United States, 2010. MMWR Surveill Summ 2014;63:1-21.

3. Fox LC. Physical activity and adolescent girls with ASD: effects of an individualized exercise program on cognitive, social, and physical-health indicators [Doctoral dissertation]. Chapel Hill, NC, USA: The University of North Carolina at Chapel Hill; 2014.

4-Samadi SA, McConkey R. Screening for autism in Iranian preschoolers: Contrasting M-CHAT and a scale developed in Iran. J Autism Dev Disord. J Autism Dev Disord 2015;45:2908-16.

5.Schwarz E, Guest PC, Rahmoune H, Wang L, Levin Y, Ingudomnukul E, et al. Sex-specific serum biomarker patterns in adults with Asperger's syndrome. Mol Psychiatry 201;16:12-13. 
6-Ming X, Brimacombe M, Chaaban J, Zimmerman-Bier B, Wagner GC. Autism spectrum disorders: concurrent clinical disorders. J Child Neurol 2008;23:6-13.

7-Nazary Sharif H, Daneshmandi H, Norasteh AA, Aboutalebi S. Postural Profile in Children with Autism. J Mazandaran Univ Med Sci 2016;26:79-1.

8-Ashwood P, Krakowiak P, Hertz-Picciotto I, Hansen R, Pessah I, Van de Water J. Elevated plasma cytokines in autism spectrum disorders provide evidence of immune dysfunction and are associated with impaired behavioral outcome. Brain Behav Immun 2011;25:40-5.

9-Suzuki K, Matsuzaki H, Iwata K, Kameno Y, Shimmura C, Kawai S, et al. Plasma cytokine profiles in subjects with high-functioning autism spectrum disorders. PloS One 2011; 6:e20470.

10-Jyonouchi H, Sun S, Le H. Proinflammatory and regulatory cytokine production associated with innate and adaptive immune responses in children with autism spectrum disorders and developmental regression. J Neuroimmunol 2001; 120:170-9.

11-Masi A, Glozier N, Dale R, Guastella AJ. The immune system, cytokines, and biomarkers in autism spectrum disorder. Neurosci Bull 2017; 33:194-204.

12-Goines PE, Ashwood P. Cytokine dysregulation in autism spectrum disorders (ASD): possible role of the environment. Neurotoxicol Teratol 2013;36:67-81.

13-Dantzer R. Cytokine-induced sickness behavior: where do we stand? Brain Behav Immun 2001;15:7-24.

14-Croonenberghs J, Bosmans E, Deboutte D, Kenis G, Maes M. Activation of the inflammatory response system in autism. Neuropsychobiology 2002; 45:1-6.

15-Chez MG, Dowling T, Patel PB, Khanna P, Kominsky M. Elevation of tumor necrosis factor-alpha in cerebrospinal fluid of autistic children. Pediatr Neurol 2007;36:361-5.

16-Wieseler-Frank J, Maier SF, Watkins LR. Glial activation and pathological pain. Neurochem Int 2004;45:389-95.

17-Li X, Chauhan A, Sheikh AM, Patil S, Chauhan V, Li XM, et al. Elevated immune response in the brain of autistic patients. J Neuroimmunol 2009; 207:111-6.

18-Singh VK. Plasma increase of interleukin-12 and interferon-gamma. Pathological significance in autism. J Neuroimmunol 1996;66:143-5.

19-Moore KW, de Waal Malefyt R, Coffman RL, O'Garra A. Interleukin-10 and the interleukin-10 receptor. Annu Rev Immunol 2001;19:683-765.

20-Molloy CA, Morrow AL, Meinzen-Derr J, Schleifer K, Dienger K, Manning-Courtney P, et al. Elevated cytokine levels in children with autism spectrum disorder. J Neuroimmunol 2006;172:198-205.

21-Khakzad MR, Javanbakht M, Shayegan MR, Kianoush S, Omid F, Hojati M, et al. The complementary role of high sensitivity C-reactive protein in the diagnosis and severity assessment of autism. Res Autism Spectr Disord 2012; 6:1032-7.

22-Szalai AJ. The biological functions of C-reactive protein. Vascul Pharmacol 2002;39:105-7.

23-Qian FH, Zhang Q, Zhou LF, Liu H, Huang M, Zhang XL, et al. High-sensitivity C-reactive protein: a predicative marker in severe asthma. Respirology 2008;13:664-9.

24-Chenillot O, Henny J, Steinmetz J, Herbeth B, Wagner C, Siest G. High sensitivity C-reactive protein: biological variations and reference limits. Clin Chem Lab Med 2000;38:1003-11.

25-Gilliam JE. Gilliam autism rating scale: GARS 2. Pro-ed. Second Edition. Austin, TX: PRO-ED; 2006.

26-Ricci S, Businaro R, Ippoliti F, Vasco VL, Massoni F, Onofri E, et al. Altered cytokine and BDNF levels in autism spectrum disorder. Neurotox Res. 2013; 24:491-501.

27-Filiano AJ, Gadani SP, Kipnis J. Interactions of innate and adaptive immunity in brain development and function. Brain Res 2015;1617:18-27.

28-Capuron L, Miller AH. Immune system to brain signaling: neuropsychopharmacological implications. Pharmacol Ther 2011;130:226-38.

29-Mead J, Ashwood P. Evidence supporting an altered immune response in ASD. Immunol Lett 2015;163:49-55.

30-Ross HE, Guo Y, Coleman K, Ousley O, Miller AH. Association of IL-12p70 and IL-6: IL-10 ratio with autismrelated behaviors in 22q11. 2 deletion syndrome: a preliminary report. Brain Behav Immun 2013;31:76-81. 